\title{
Effect of Organic and Inorganic Salts on the Development of Helminthosporium solani, the Causal Agent of Potato Silver Scurf
}

\author{
V. Hervieux, E. S. Yaganza, J. Arul, and R. J. Tweddell, Centre de Recherche en Horticulture, Université Laval, \\ Québec, Québec, Canada, G1K 7P4
}

\begin{abstract}
Hervieux, V., Yaganza, E. S., Arul, J., and Tweddell, R. J. 2002. Effect of organic and inorganic salts on the development of Helminthosporium solani, the causal agent of potato silver scurf. Plant Dis. 86:1014-1018.

Potato silver scurf, caused by Helminthosporium solani, is an important postharvest disease of economic significance. Control of $H$. solani has been accomplished primarily by postharvest applications of thiabendazole. However, many strains of $H$. solani have become resistant to thiabendazole, resulting in failure of disease control. Consequently, alternative control strategies are needed. This study showed that several salts significantly reduced silver scurf development on potato tuber at a concentration of $0.2 \mathrm{M}$ and that the timing of application also influenced salt efficacy. Among the 23 tested salts, aluminum chloride was the only one reducing silver scurf severity when applied either 2,4 , or 7 days after $H$. solani inoculation. Aluminum lactate, potassium sorbate, sodium carbonate, sodium metabisulfite, and trisodium phosphate also markedly reduced silver scurf severity but only when applied 2 or 4 days after inoculation. Ammonium acetate, calcium chloride, sodium benzoate, sodium citrate, and sodium formate reduced disease severity by at least $50 \%$ when applied 2 days after $H$. solani inoculation. With the exception of calcium chloride and sodium formate, these salts also were shown to strongly inhibit $H$. solani mycelial growth or spore germination in vitro. Results of this study further demonstrate the possibility of using selected salts for the control of potato silver scurf.
\end{abstract}

Additional keywords: conidiation, ion

Silver scurf disease of potato (Solanum tuberosum L.), caused by the fungus Helminthosporium solani Durieu \& Mont., is a surface-blemishing disease spoiling the appearance of potato tubers (29). Silver scurf-diseased tubers show a metallic discoloration of the periderm in irregular patterns (32). Portions of tuber periderm may eventually slough off and cause fresh weight loss during storage (22). Infection often takes place during the growing season (11) and lesions may be visible at harvest. Disease severity increases greatly during long-term storage of tubers as a result of lesion expansion and repeated cycles of sporulation and infection (22,30). Long recognized as a disease of minor importance, silver scurf, present in most potato-growing areas (35), has emerged during the 1990s as an economically important disease of commercial potato production $(7,33)$.

Corresponding author: R. J. Tweddell

E-mail: russell.tweddell@crh.ulaval.ca

Financial support from the Conseil de recherches en pêche et en agroalimentaire du Québec (CORPAQ), Cultures H. Dolbec Inc., and Propur Inc. is gratefully acknowledged.

Accepted for publication 15 May 2002.

Publication no. D-2002-0719-02R

(C) 2002 The American Phytopathological Society
Control of $H$. solani has been accomplished primarily by postharvest applications of thiabendazole, a benzimidazole fungicide (32). However, many strains of $H$. solani have become resistant to thiabendazole $(14,26,32)$, resulting in increased incidence and severity of silver scurf. This situation has led to other chemicals being tested for the control of potato silver scurf (7). Several fungicides, including imazalil, mancozeb, and fludioxonil, were tested as preplanting seed tuber treatments. These fungicides were shown to effectively control silver scurf, but only under certain experimental conditions $(2,8-10,12,15)$. Although cultural practices such as crop rotation, appropriate management of potato storage areas, and chemical seed tuber treatment can help reduce silver scurf (7), alternative control strategies are needed.

An interesting alternative to fungicide application for plant disease control involves the use of some organic and inorganic salts with antimicrobial properties generally used in food processing and preservation. Many of these salts show several advantages for utilization as postharvest chemicals, such as a broad spectrum of antimicrobial activity, a low mammalian toxicity $(22,23)$, and a relatively low cost. Several studies have dealt with the use of different salts to control various postharvest diseases of potato and other crops. Treatment of citrus fruit with sodium carbonate or sodium bicarbonate was shown to reduce the incidence of postharvest disease caused by Penicillium digitatum (34). Postharvest application of ammonium bicarbonate, sodium bicarbonate, potassium carbonate, calcium propionate, and potassium sorbate reduced black root rot on carrots caused by Chalara elegans (27). Recent studies suggest that salt application reduces postharvest potato diseases. Olivier et al. (22) showed that application of potassium sorbate, calcium propionate, sodium carbonate, sodium bicarbonate, potassium carbonate, potassium bicarbonate, and ammonium bicarbonate at $0.2 \mathrm{M}$ reduced silver scurf lesion development and $H$. solani sporulation on inoculated and naturally infected potato tubers. Sodium metabisulfite and aluminum chloride $(0.2 \mathrm{M})$ were shown to reduce the development of potato dry rot (17) and soft rot (36) caused by Fusarium sambucinum and Erwinia carotovora, respectively.

As a part of ongoing research on the control of postharvest potato diseases, the objectives of this study were to (i) evaluate the effect of different salts on growth and development of $H$. solani in vitro and (ii) evaluate the efficacy of these salts for reducing silver scurf severity in potato tubers.

\section{MATERIALS AND METHODS}

Fungal isolate. $H$. solani (strain UAMH 4172) was obtained from the University of Alberta (Edmonton, Canada). The fungus was maintained on V8-juice agar (V8 agar) slants. V8 agar was prepared as described by Olivier et al. (22) and adjusted to $\mathrm{pH}$ 7.2. Agar slants were stored at $4{ }^{\circ} \mathrm{C}$ and served as stock cultures.

Potato. Tubers of the cultivar Dark Red Norland produced in sterile vermiculite substrate in the greenhouse were obtained from Semences Saguenoises Inc. (Petit Saguenay, Canada). Potato tubers were stored in the dark at $4^{\circ} \mathrm{C}$ until use.

Chemicals. Ammonium acetate and sodium acetate were purchased from BDH Inc. (Toronto, Canada) and Fisher Scientific Ltd (Pittsburgh, PA), respectively. Sodium and potassium chloride were purchased from Anachemia (Montréal, Canada). The other salts were obtained from Sigma-Aldrich (St. Louis, MO).

Effect of salts on in vitro mycelial growth and conidiation. $H$. solani was grown at $24^{\circ} \mathrm{C}$ on V8 agar plates amended 
with one of the test salts $(0.2 \mathrm{M})$ or on unamended control plates (22). Agar plugs ( $9 \mathrm{~mm}$ in diameter) excised from the edge of actively growing mycelium of $\mathrm{H}$. solani were used to inoculate the plates. After 5 weeks of growth, colony diameter and spore number were evaluated. Colony diameter was measured as the average of the longest and the shortest diameters. Each colony then was removed using a scalpel, placed into a centrifuge tube containing sterile double-distilled water (30 $\mathrm{ml})$, and vortexed (60 s) to dislodge conidia. The suspension was filtered through four layers of cheese cloth. The spores then were counted using a hemacytometer (Hausser Scientific Company, Horsham, PA). For each plate, conidia per square centimeter of colony was calculated. The experimental design was a completely randomized block with five replicates. The results were expressed as percent mycelial growth or conidiation inhibition: ([radial growth or number of conidia (control) radial growth or number of conidia (salt amended media)]/radial growth or number of conidia [control]) $\times 100$.

Effect of salts on in vitro spore germination. Spore suspensions $(200 \mu \mathrm{l} ; 500$ spores $\mathrm{ml}^{-1}$ ) were spread on V8 agar plates amended with the test salts $(0.2 \mathrm{M})$ or on unamended control plates. Plates were incubated in the dark at $24^{\circ} \mathrm{C}$ for a 12-day period. The germination of conidia then was evaluated. The experimental design was a completely randomized block with two replicates. The results were expressed as spore germination inhibition: ([spore germination percentage (control) - spore germination percentage (salt amended media)]/spore germination percentage [control]) $\times 100$.

Effect of medium initial $\mathrm{pH}$ on mycelial growth. $H$. solani was grown at $24^{\circ} \mathrm{C}$ on $\mathrm{V} 8$ agar adjusted with $\mathrm{NaOH}$ and $\mathrm{HCl}$ to $\mathrm{pH} 3.5,4.0,5.0,6.0,7.0,8.0,9.0,10.0$, 11.0, 12.0, and 13.0. Radial growth was measured after a 6-week period of growth. A completely randomized experimental design including four replicates was used. Agar plates were inoculated as previously described.

Effect of salts on silver scurf development. Tubers were rinsed with sterile double-distilled water and air dried. A suspension of $H$. solani conidia $\left(2 \times 10^{5}\right.$ conidia $\mathrm{ml}^{-1}$ ) then was sprayed on potato tubers until run-off (22). Tubers were incubated in the dark at $24^{\circ} \mathrm{C}$ (relative humidity $\approx 95 \%$ ) for 2,4 , or 7 days. They then were dipped $(10 \mathrm{~min})$ in the different salt solutions $(0.2$ $\mathrm{M})$ or in double-distilled water (control) and subsequently stored (single layer of tubers) in the dark at $15^{\circ} \mathrm{C}$ in plastic chambers (relative humidity $\approx 95 \%$ ) for 6 weeks. Silver scurf severity then was evaluated on each tuber. A completely randomized experimental design including three replicates was used. Results were expressed as percent disease reduction: ([disease severity (control tubers) - disease severity (salt-treated tubers)]/disease severity [control tubers] $) \times 100$.

Disease severity assessment. Silver scurf severity was evaluated according to the slightly modified method of Elson et al. (6). On each tuber, 10 periderm discs were randomly cut off with a cork-borer and rated for the presence of $H$. solani conidiophores using a stereomicroscope. The disease severity was expressed as the percentage of potato tuber surface covered with $H$. solani conidiophores.

Data analysis. Analysis of variance was carried out with the GLM procedure of SAS (SAS Institute, Cary, NC). When significant $(P<0.05)$, treatment means were compared using Fisher's protected least significant difference. Experiments were conducted twice in vitro and in potato tubers.

\section{RESULTS}

In all, 11 inorganic and 12 organic salts were evaluated at a concentration of $0.2 \mathrm{M}$ for their inhibitory activity against $H$. solani in vitro. Several salts significantly inhibited mycelial growth and spore germination of $H$. solani (Table 1). Aluminum salts, phosphate salts, potassium sorbate, sodium benzoate, sodium bicarbonate, sodium carbonate, sodium citrate, and sodium metabisulfite completely or almost completely inhibited spore germination. These salts also strongly inhibited mycelial growth, with the exception of sodium citrate and sodium benzoate, which displayed a slighter inhibitory effect on the mycelial growth. Ammonium acetate strongly inhibited mycelial growth and, to a lesser extent, spore germination. The other salts displayed only weak inhibitory effects. When mycelial growth was observed, the effect of salts on conidiation was evaluated. Salts significantly influenced $H$. solani conidiation (Table 1). Ammonium acetate, diammonium phosphate, disodium phosphate, sodium benzoate, sodium bicarbonate, and sodium propionate, which reduced mycelial growth by at least $50 \%$, also reduced

Table 1. Effect of salts on Helminthosporium solani spore germination, mycelial growth, and conidiation in vitro ${ }^{\mathrm{y}}$

\begin{tabular}{|c|c|c|c|c|}
\hline Salt & $\mathbf{p H}^{\mathbf{z}}$ & $\begin{array}{l}\text { Spore germination } \\
\text { inhibition }(\%)\end{array}$ & $\begin{array}{c}\text { Mycelial growth } \\
\text { inhibition }(\%)\end{array}$ & $\begin{array}{c}\text { Conidiation } \\
\text { inhibition (\%) }\end{array}$ \\
\hline Aluminum acetate $\left(\mathrm{C}_{2} \mathrm{H}_{5} \mathrm{O}_{4} \mathrm{Al}\right)$ & 5.0 & $100.0 \mathrm{a}$ & $100.0 \mathrm{a}$ & ND \\
\hline Aluminum chloride $\left(\mathrm{AlCl}_{3} \cdot 6 \mathrm{H}_{2} \mathrm{O}\right)$ & 3.0 & $100.0 \mathrm{a}$ & $100.0 \mathrm{a}$ & ND \\
\hline Aluminum lactate $\left(\left(\mathrm{C}_{3} \mathrm{H}_{5} \mathrm{O}_{3}\right)_{3} \mathrm{Al}\right)$ & 3.5 & $100.0 \mathrm{a}$ & $100.0 \mathrm{a}$ & ND \\
\hline Ammonium acetate $\left(\mathrm{NH}_{4} \mathrm{C}_{2} \mathrm{H}_{3} \mathrm{O}_{2}\right)$ & 7.1 & $60.0 \mathrm{bc}$ & $94.1 \mathrm{a}$ & 71.8 abcde \\
\hline Ammonium chloride $\left(\mathrm{NH}_{4} \mathrm{Cl}\right)$ & 6.9 & 29.1 ef & $25.6 \mathrm{ef}$ & 74.1 abcde \\
\hline Calcium chloride $\left(\mathrm{CaCl}_{2} \cdot 2 \mathrm{H}_{2} \mathrm{O}\right)$ & 6.6 & 46.3 cde & $3.0 \mathrm{gh}$ & $-97.4 \mathrm{~h}$ \\
\hline Diammonium phosphate $\left(\left(\mathrm{NH}_{4}\right)_{2} \mathrm{HPO}_{4}\right)$ & 7.9 & $100.0 \mathrm{a}$ & $91.9 \mathrm{a}$ & 72.7 abcde \\
\hline Disodium phosphate $\left(\mathrm{Na}_{2} \mathrm{HPO}_{4} \cdot 7 \mathrm{H}_{2} \mathrm{O}\right)$ & 8.4 & $100.0 \mathrm{a}$ & $95.2 \mathrm{a}$ & 89.9 abc \\
\hline Potassium chloride $(\mathrm{KCl})$ & 7.2 & $38.7 \mathrm{de}$ & $-4.4 \mathrm{~h}$ & 19.6 cdefg \\
\hline Potassium sorbate $\left(\mathrm{C}_{6} \mathrm{H}_{7} \mathrm{O}_{2} \mathrm{~K}\right)$ & 7.6 & $100.0 \mathrm{a}$ & $99.0 \mathrm{a}$ & ND \\
\hline Sodium acetate $\left(\mathrm{C}_{2} \mathrm{H}_{3} \mathrm{O}_{2} \mathrm{Na}\right)$ & 7.5 & $32.3 \mathrm{def}$ & $15.7 \mathrm{fg}$ & $4.4 \mathrm{efg}$ \\
\hline Sodium benzoate $\left(\mathrm{C}_{7} \mathrm{H}_{5} \mathrm{O}_{2} \mathrm{Na}\right)$ & 7.3 & $100.0 \mathrm{a}$ & $70.9 \mathrm{bc}$ & $91.1 \mathrm{abc}$ \\
\hline Sodium bicarbonate $\left(\mathrm{NaHCO}_{3}\right)$ & 8.0 & $100.0 \mathrm{a}$ & $89.9 \mathrm{ab}$ & 71.3 abcdef \\
\hline Sodium carbonate $\left(\mathrm{Na}_{2} \mathrm{CO}_{3}\right)$ & 10.7 & $100.0 \mathrm{a}$ & $100.0 \mathrm{a}$ & ND \\
\hline Sodium chloride $(\mathrm{NaCl})$ & 7.2 & $14.5 \mathrm{f}$ & $-1.98 \mathrm{gh}$ & 23.0 cdefg \\
\hline Sodium citrate $\left(\mathrm{C}_{6} \mathrm{H}_{5} \mathrm{O}_{7} \mathrm{Na}_{3} \cdot 2 \mathrm{H}_{2} \mathrm{O}\right)$ & 7.9 & $99.5 \mathrm{a}$ & $42.8 \mathrm{de}$ & $95.1 \mathrm{a}$ \\
\hline Sodium formate (HCOONa) & 7.2 & $26.0 \mathrm{ef}$ & $44.2 \mathrm{de}$ & 16.2 defg \\
\hline Sodium lactate $\left(\mathrm{C}_{3} \mathrm{H}_{5} \mathrm{O}_{3} \mathrm{Na}\right)$ & 7.4 & $25.8 \mathrm{ef}$ & $13.0 \mathrm{fgh}$ & $-36.1 \mathrm{gh}$ \\
\hline Sodium metabisulfite $\left(\mathrm{Na}_{2} \mathrm{~S}_{2} \mathrm{O}_{5}\right)$ & 4.0 & $100.0 \mathrm{a}$ & $100.0 \mathrm{a}$ & ND \\
\hline Sodium propionate $\left(\mathrm{C}_{3} \mathrm{H}_{5} \mathrm{O}_{2} \mathrm{Na}\right)$ & 7.5 & $68.4 \mathrm{~b}$ & $54.4 \mathrm{~cd}$ & $92.8 \mathrm{ab}$ \\
\hline Sodium succinate $\left(\mathrm{C}_{4} \mathrm{H}_{4} \mathrm{O}_{4} \mathrm{Na}_{2} \cdot 6 \mathrm{H}_{2} \mathrm{O}\right)$ & 7.6 & $31.2 \mathrm{ef}$ & $15.9 \mathrm{fg}$ & $79.1 \mathrm{abcd}$ \\
\hline Sodium tartrate $\left(\mathrm{C}_{4} \mathrm{H}_{4} \mathrm{O}_{6} \mathrm{Na}_{2} \cdot 2 \mathrm{H}_{2} \mathrm{O}\right)$ & 7.6 & $52.9 \mathrm{bcd}$ & $42.5 \mathrm{de}$ & $95.4 \mathrm{a}$ \\
\hline Trisodium phosphate $\left(\mathrm{Na}_{3} \mathrm{PO}_{4} \cdot 12 \mathrm{H}_{2} \mathrm{O}\right)$ & 12.3 & $100.0 \mathrm{a}$ & $100.0 \mathrm{a}$ & ND \\
\hline
\end{tabular}

${ }^{y}$ Each value represents the mean of two (spore germination inhibition) or five replicates (mycelial growth and conidiation inhibition). Values of the same column followed by the same letter are not significantly different according to Fisher's protected least significant difference $(P<0.05)$; ND $=$ not determined due to complete (or $99.0 \%$ ) inhibition of mycelial growth.

${ }^{\mathrm{z}} \mathrm{pH}$ of salt-amended media. 
the production of conidia. Sodium tartrate, sodium succinate, sodium citrate, and ammonium chloride also reduced $H$. solani conidiation, although they displayed a lower inhibitory effect on mycelial growth. Calcium chloride, which displayed a very small inhibition on mycelial growth, stimulated conidiation. Sodium lactate exhibited a modest growth inhibition and also promoted conidiation.

Considering that several salts influenced medium $\mathrm{pH}$, the effect of $\mathrm{pH}$ on $H$. solani mycelial growth was evaluated. The results

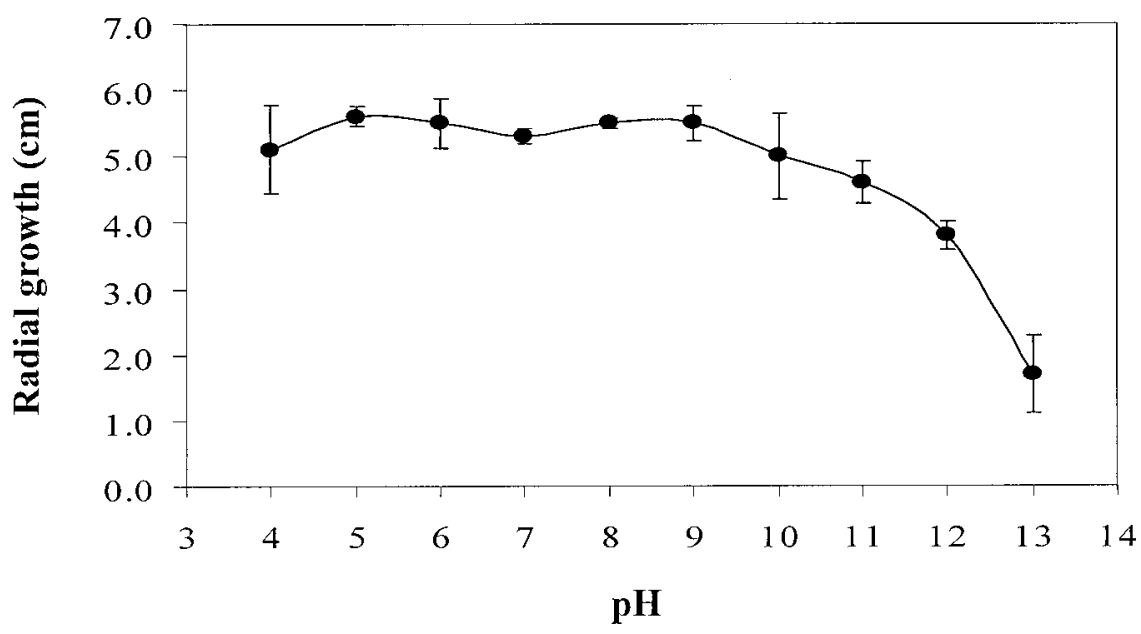

Fig. 1. Effect of medium initial $\mathrm{pH}$ on Helminthosporium solani mycelial growth. H. solani was grown at $24^{\circ} \mathrm{C}$ on V8-juice agar adjusted to different $\mathrm{pH}$ for a 6-week period. Radial growth then was measured. Each value represents the mean of four replicates with standard deviation bar.

Table 2. Effect of salts on potato tuber silver scurf development ${ }^{2}$

\begin{tabular}{lccc}
\hline & \multicolumn{3}{c}{ Disease reduction (\%) } \\
\cline { 2 - 4 } Salt & $\mathbf{2 ~ d a y s}$ & $\mathbf{4 ~ d a y s}$ & $\mathbf{7 ~ d a y s ~}$ \\
\hline Aluminum acetate & $46.7 \mathrm{cde}$ & $13.3 \mathrm{def}$ & $0.0 \mathrm{c}$ \\
Aluminum chloride & $90.0 \mathrm{a}$ & $80.0 \mathrm{a}$ & $83.3 \mathrm{a}$ \\
Aluminum lactate & $80.0 \mathrm{ab}$ & $70.0 \mathrm{ab}$ & $3.3 \mathrm{bc}$ \\
Ammonium acetate & $63.3 \mathrm{bcd}$ & $10.0 \mathrm{ef}$ & $0.0 \mathrm{c}$ \\
Ammonium chloride & $3.3 \mathrm{~g}$ & $0.0 \mathrm{f}$ & $0.0 \mathrm{c}$ \\
Calcium chloride & $83.3 \mathrm{ab}$ & $0.0 \mathrm{f}$ & $0.0 \mathrm{c}$ \\
Diammonium phosphate & $43.3 \mathrm{de}$ & $0.0 \mathrm{f}$ & $0.0 \mathrm{c}$ \\
Disodium phosphate & $43.3 \mathrm{de}$ & $0.0 \mathrm{f}$ & $0.0 \mathrm{c}$ \\
Potassium chloride & $0.0 \mathrm{~g}$ & $0.0 \mathrm{f}$ & $0.0 \mathrm{c}$ \\
Potassium sorbate & $83.3 \mathrm{ab}$ & $60.0 \mathrm{bc}$ & $0.0 \mathrm{c}$ \\
Sodium acetate & $43.3 \mathrm{de}$ & $3.3 \mathrm{f}$ & $0.0 \mathrm{c}$ \\
Sodium benzoate & $66.7 \mathrm{bc}$ & $26.7 \mathrm{de}$ & $0.0 \mathrm{c}$ \\
Sodium bicarbonate & $26.7 \mathrm{ef}$ & $3.3 \mathrm{f}$ & $0.0 \mathrm{c}$ \\
Sodium carbonate & $80.0 \mathrm{ab}$ & $50.0 \mathrm{c}$ & $0.0 \mathrm{c}$ \\
Sodium chloride & $6.67 \mathrm{fg}$ & $0.0 \mathrm{f}$ & $0.0 \mathrm{c}$ \\
Sodium citrate & $50.0 \mathrm{~cd}$ & $6.7 \mathrm{f}$ & $0.0 \mathrm{c}$ \\
Sodium formate & $53.3 \mathrm{~cd}$ & $0.0 \mathrm{f}$ & $0.0 \mathrm{c}$ \\
Sodium lactate & $16.7 \mathrm{fg}$ & $30.0 \mathrm{~d}$ & $0.0 \mathrm{c}$ \\
Sodium metabisulfite & $93.3 \mathrm{a}$ & $85.0 \mathrm{a}$ & $0.0 \mathrm{c}$ \\
Sodium propionate & $26.7 \mathrm{ef}$ & $0.0 \mathrm{f}$ & $0.0 \mathrm{c}$ \\
Sodium succinate & $16.7 \mathrm{fg}$ & $0.0 \mathrm{f}$ & $0.0 \mathrm{c}$ \\
Sodium tartrate & $26.7 \mathrm{ef}$ & $0.0 \mathrm{f}$ & $0.0 \mathrm{c}$ \\
Trisodium phosphate & $76.7 \mathrm{ab}$ & $60.0 \mathrm{bc}$ & $6.7 \mathrm{~b}$ \\
\hline
\end{tabular}

${ }^{\mathrm{z}}$ A suspension of Helminthosporium solani conidia was sprayed on potato tubers. Tubers were incubated in the dark at $24^{\circ} \mathrm{C}$ for 2,4 , or 7 days. They then were dipped in the different salt solutions $(0.2 \mathrm{M})$ or in double-distilled water (control) and subsequently stored at $15^{\circ} \mathrm{C}$ for 6 weeks. Silver scurf severity was evaluated on each tuber. Disease reduction was calculated as follows: ([disease severity (control tubers) - disease severity (salt treated tubers)]/disease severity [control tubers]) $\times$ 100. Each value represents the mean of three replicates. Values of the same column followed by the same letter are not significantly different according to Fisher's protected least significant difference $(P<0.05)$. num chloride, aluminum lactate, calcium chloride, potassium sorbate, sodium benzoate, sodium carbonate, sodium metabisulfite, sodium citrate, sodium formate, ammonium acetate, and trisodium phosphate reduced silver scurf severity by at least $50 \%$. When applied 4 days after inoculation, only six salts markedly reduced disease severity. Sodium metabisulfite, aluminum chloride, aluminum lactate, potassium sorbate, trisodium phosphate, and sodium carbonate reduced silver scurf severity by $85,80,70,60,60$, and $50 \%$, respectively. Aluminum chloride was the only salt that strongly reduced silver scurf severity when applied 7 days after $H$. solani inoculation.

\section{DISCUSSION}

Several salts at a concentration of $0.2 \mathrm{M}$ strongly reduced $H$. solani mycelial growth, spore germination, or both. Salts reducing mycelial growth generally also reduced conidiation. Among the salts which only slightly inhibited mycelial growth, sodium succinate reduced conidiation, whereas calcium chloride stimulated it. Given that $H$. solani growth is relatively good between $\mathrm{pH} 4.0$ and 12.0, the inhibition observed in the salt-amended media displaying a $\mathrm{pH}$ in this range cannot be due to a direct effect of $\mathrm{pH}$ on the fungus. The comparison of the inhibitory effect of the various salts permits the identification of the ions affecting the fungus.

The organic anions, benzoate and sorbate, strongly inhibited $H$. solani development in vitro. Antimicrobial activity of potassium sorbate was shown previously on H. solani (22) and Sclerotium rolfsii (28). Benzoate also was shown to display antimicrobial activity (5). Postulated mechanisms by which these anions inhibit microorganisms include alteration of the activity of Krebs cycle enzymes as well as the integrity of cell membranes $(22,31)$. In our study, citrate also inhibited $H$. solani. The inhibitory effect of citric acid $(0.5 \%)$ also was observed on Aspergillus parasiticus mycelial growth and production of sclerotia (1).

Sodium metabisulfite and other sulfiting agents (sulfur dioxide and sodium bisulfite) are being used as food ingredients for multiple reasons, including antimicrobial function. The inhibitory effect of sulfites on yeasts, molds, and bacteria has been well documented (16,31). Sodium metabisulfite was shown to inhibit $A$. parasiticus (1), F. sambucinum (17), and Botrytis cinerea (25) mycelial growth. In the present study, sodium metabisulfite, which is predominantly in the forms of bisulfite ions and undissociated sulfurous acid at $\mathrm{pH} 4.0$, completely inhibited $H$. solani mycelial growth as well as spore germination. Postulated mechanisms by which sulfites inhibit microorganisms include reactions with protein carbonyl groups, $\mathrm{FAD}^{+}$, RNA, and DNA (31). 
Sodium carbonate $(\mathrm{pH}$ 10.7) and bicarbonate ( $\mathrm{pH} 8.0)$ strongly inhibited mycelial growth and spore germination of $H$. solani. The inhibitory effect of carbonate or bicarbonate salts at $0.2 \mathrm{M}$ was previously observed on $H$. solani mycelial growth (22). Considering that the proportion of $\mathrm{CO}_{3}{ }^{2-}$ ion is high at $\mathrm{pH} 10.7$ and that $\mathrm{HCO}_{3}{ }^{-}$is the predominant ion at $\mathrm{pH} 8.0(25)$, the results suggest that both the $\mathrm{HCO}_{3}{ }^{-}$and $\mathrm{CO}_{3}{ }^{2-}$ forms displayed an inhibitory activity on mycelial growth and spore germination. On the other hand, trisodium phosphate $(\mathrm{pH}$ 12.3) and disodium phosphate (pH 8.4) completely inhibited $H$. solani spore germination and strongly reduced mycelial growth, suggesting that the ion $\mathrm{HPO}_{4}{ }^{2-}$ (predominant ion at $\mathrm{pH} 8.4$ and 12.3) exerts an inhibitory effect on $\mathrm{H}$. solani. The inhibitory effect of disodium phosphate previously was observed on $B$. cinerea mycelial growth (25). Dibasic phosphate and bicarbonate ions may alter normal membrane activities (25).

Some of the ammonium salts tested also displayed an inhibitory effect on $H$. solani. Although Punja and Grogan (28), Depasquale et al. (3), and Palmer et al. (25) reported that ammonium salts were inhibitory under alkaline conditions where $\mathrm{NH}_{3}$ (membrane permeable) is favored over the ineffective $\mathrm{NH}_{4}{ }^{+}$form, our results suggest that ammonium salts do display a certain level of inhibition at neutral $\mathrm{pH}$.

Aluminum lactate, acetate, and chloride completely inhibited mycelial growth and spore germination. Although, in the case of aluminum chloride and aluminum lactate, the $\mathrm{pH}$ of the media is likely to play a role in the observed inhibition, the results suggest that aluminum ions have an inhibitory effect. Aluminum was shown to inhibit mycelial growth or spore germination of several fungi, including Thielaviopsis basicola (18), F. sambucinum (17), Phytophthora capsici (21), and Verticillium albo-atrum (24). The mechanisms by which aluminum ion inhibits the growth and spore germination may involve cellular ionic imbalance (19) and calmodulin inactivation (18). In addition, aluminum also was shown to affect cell division as well as DNA synthesis (19). The observed inhibiting effect of aluminum on $H$. solani can be attributed to one or several of these mechanisms.

The application of aluminum chloride, aluminum lactate, potassium sorbate, calcium chloride, sodium carbonate, trisodium phosphate, and sodium metabisulfite by dipping the tubers markedly decreased silver scurf severity on the infected tubers. Application of sodium carbonate, potassium sorbate, and calcium chloride has been shown previously to reduce silver scurf lesion development on potato tubers $(22,23)$. On the other hand, aluminum chloride, which is the active component of the fungicide Synermix (13), is reported to be effective against Botrytis mold on grapevines, especially in combination with iprodione. This salt also was shown to reduce development of dry rot and soft rot on potato tubers $(17,36)$. Application of sodium metabisulfite controlled pear fruit rots caused by Alternaria alternata and Mucor piriformis (4) and reduced development of potato dry rot (17) and soft rot (36). This study shows that application of ammonium acetate, sodium benzoate, sodium formate, and sodium citrate also decreased silver scurf development by $50 \%$ or more.

Furthermore, the timing of salt application, in addition to salt types, was important in the inhibition of silver scurf development. Our results show that aluminum chloride was the only salt that reduced silver scurf severity when applied either 2 , 4 , or 7 days after $H$. solani inoculation. Aluminum lactate, potassium sorbate, sodium carbonate, sodium metabisulfite, and trisodium phosphate reduced silver scurf severity if applied 2 or 4 days after inoculation. Ammonium acetate, calcium chloride, sodium benzoate, sodium citrate, and sodium formate showed efficacy, but only when applied 2 days after $H$. solani inoculation. Heiny and McIntyre (11) studied $H$. solani development on potato tubers. They showed that spore germination occurred within $16 \mathrm{~h}$ after inoculation and that appressorium formation and periderm penetration were observed 48 and $96 \mathrm{~h}$ after inoculation, respectively. Considering these observations, our study suggests that aluminum chloride is the only salt capable of inhibiting $H$. solani once the fungus has penetrated the periderm. Ammonium acetate, calcium chloride, sodium benzoate, sodium citrate, and sodium formate seem to affect specifically appressorium formation or the early events of penetration, whereas aluminum lactate, potassium sorbate, sodium carbonate, sodium metabisulfite, and trisodium phosphate seem to affect appressorium formation, periderm penetration, or both.

The present study suggests that in vitro inhibition cannot predict the potential of a salt to control silver scurf on potato tubers, and that some salts loose their inhibitory effect in the tripartite pathogen-tuber-salt interactions. Indeed, aluminum acetate, diammonium phosphate, disodium phosphate, and sodium bicarbonate strongly inhibited mycelial growth and spore germination but displayed a relatively slight inhibition in disease severity. On the other hand, calcium chloride showed almost no inhibitory activity on mycelial growth and only a relatively slight inhibitory effect on spore germination, but strongly reduced silver scurf severity when applied 2 days after tuber inoculation. This result suggests that specific salt-tissue interactions may involve biochemical reactions, such as defense mechanisms contributing to the control of silver scurf. Some salts, including aluminum chloride and potassium phosphate, are in fact known to induce plant defenses or systemic resistance $(13,20)$. Moreover, several salts inhibited $H$. solani development in vitro, but only aluminum chloride reduced silver scurf severity when applied 7 days after $H$. solani inoculation.

In conclusion, our results show, for the first time, that several salts (aluminum chloride, aluminum lactate, sodium metabisulfite, and trisodium phosphate) reduce $H$. solani mycelial growth and spore germination in vitro as well as silver scurf development on potato tuber. Among these salts, aluminum chloride is particularly of interest because it is effective when applied 2, 4, or 7 days after $H$. solani inoculation, while aluminum lactate, sodium metabisulfite, and trisodium phosphate display efficacy only when applied 2 or 4 days after inoculation. The results of this study advance the possibility of using selected salts to control potato silver scurf on either seed or warehouse potato tubers for human consumption. However, further work is necessary with the selected salts to evaluate their efficacy against several strains of $H$. solani in several potato cultivars in order to establish whether salt application could eventually be integrated into disease control strategies for potato (22). In addition, it is also important to evaluate the effect of salt application on the quality of the tubers. Olivier et al. (23) observed, with cvs. Chieftain and Monona, that potassium sorbate and sodium carbonate influence tuber periderm coloration, suggesting that certain salts may have adverse effects on tuber coloration of some cultivars.

\section{LITERATURE CITED}

1. Chourasia, H. K. 1993. Growth, sclerotia and aflatoxin production by Aspergillus parasiticus: Influence of food preservatives. Lett. Appl. Microbiol. 17:204-207.

2. Collet-Elimane, R., and Jouan, B. 1993. Étude de possibilités de traitement contre l'Helminthosporium solani agent de la gale argentée de la pomme de terre. Pages 485-486 in: 12th Conf. Eur. Assoc. Potato Res., Paris, France.

3. Depasquale, D. A., El-Nabarawy, A., Rosen, J. D., and Montville, T. J. 1990. Ammonium bicarbonate inhibition of mycotoxigenic fungi and spoilage yeasts. J. Food Prot. 53:324-328.

4. El-Sheikh-Aly, M. M., Felaifel, M. S. A. Fouad, N. A., and Badawy, H. M. A. 1998. Comparative effectiveness of some fungicides and salts applied preharvest or postharvest for controlling pear fruit rots. Ann. Agric. Sci. (Cairo) Special Issue 1:135-149.

5. El-Shenawy, M. A., and Marth, E. H. 1988 Sodium benzoate inhibits growth of or inactivates Listeria monocytogenes. J. Food Prot. 51:525-530.

6. Elson, M. K., Schisler, D. A., and Bothast, R J. 1997. Selection of microorganisms for biological control of silver scurf (Helminthosporium solani) of potato tubers. Plant Dis. 81:647-652.

7. Errampalli, D., Saunders, J. M., and Holley, J. D. 2001. Emergence of silver scurf (Helminthosporium solani) as an economically important disease of potato. Plant Pathol. 50:141-153. 
8. Frazier, M. J., Shetty, K. K., Kleinkopf, G. E., and Nolte, P. 1998. Management of silver scurf (Helminthosporium solani) with fungicide seed treatments and storage practices. Am. J. Potato Res. 75:129-135.

9. Geary, B., Hamm, P. B., Johnson, D. A., James, S. R., and Rykbost, K. A. 2000. Effects of fungicides and location on development of silver scurf. (Abstr.) Am. J. Potato Res. 77:399.

10. Hall, S. M., and Hide, G. A. 1992. Fungicide treatment of seed tubers infected with thiabendazole-resistant Helminthosporium solani and Polyscytalum pustulans for controlling silver scurf and skin spot on stored progeny tubers. Potato Res. 35:143-147.

11. Heiny, D. K., and McIntyre, G. A. 1983. Helminthosporium solani Dur. \& Mont. development on potato periderm. Am. Potato J. 60:773-789.

12. Hervieux, V., Chabot, R., Arul, J., and Tweddell, R. J. 2001. Evaluation of different fungicides applied as seed tuber treatments for the control of potato silver scurf. Phytoprotection 82:41-48.

13. Jeandet, P., Adrian, M., Breuil, A. C., Sbaghi, M., Debord, S., Bessis, R., Weston, L. A., and Harmon, R. 2000. Chemical induction of phytoalexin synthesis in grapevines: Application to the control of grey mould in the vineyard. Proc. 7th Int. Symp. Grapevine Genet. Breed. A. Bouquet and J.-M. Boursiquot, eds. Acta Hortic. 528:591-596.

14. Kawchuk, L. M., Holley, J. D., Lynch, D. R., and Clear, R. M. 1994. Resistance to thiabendazole and thiophanate-methyl in Canadian isolates of Fusarium sambucinum and Helminthosporium solani. Am. Potato J. 71:185-192.

15. Le Corre, P., Bedin, P., Dusson, G., and Salvan, M. 1993. Efficacité du mancozebe dans le cadre de la lutte contre la gale argentée. Pages 487-488 in: 12th Conf. Eur. Assoc. Potato Res., Paris, France.

16. Lindsay, R. C. 1985. Food additives. Pages 629-687 in: Food Chemistry. 2nd ed. O. R.
Fennema, ed. Marcel Dekker Inc., New York.

17. Mecteau, M. 2001. Évaluation de l'application post-récolte de sels pour lutter contre la pourriture sèche de la pomme de terre. M.Sc. Thesis \#19219, Université Laval, Québec, Canada.

18. Meyer, J. R., Shew, H. D., and Harrison, U. J. 1992. Inhibition of germination and growth of Thielaviopsis basicola by aluminum and a calmodulin antagonist. (Abstr.) Phytopathology 82:1114.

19. Minocha, R., Minocha, S. C., Long, S. L., and Shortle, W. C. 1992. Effects of aluminum on DNA synthesis, cellular polyamines, polyamine biosynthetic enzymes and inorganic ions in cell suspension cultures of a woody plant, Catharanthus roseus. Physiol. Plant. 85:417-424.

20. Mucharromah, E., and Kuc, J. 1991. Oxalate and phosphates induce systemic resistance against diseases caused by fungi, bacteria and viruses in cucumber. Crop Prot. 10:265-270.

21. Muchovej, J. J., Maffia, L. A., and Muchovej, R. M. C. 1980. Effect of exchangeable soil aluminum and alkaline calcium salts on the pathogenicity and growth of Phytophthora capsici from green pepper. Phytopathology 70:1212-1214.

22. Olivier, C., Halseth, D. E., Mizubuti, E. S. G., and Loria, R. 1998. Postharvest application of organic and inorganic salts for suppression of silver scurf on potato tubers. Plant Dis. 82:213-217.

23. Olivier, C., MacNeil, C. R., and Loria, R. 1999. Application of organic and inorganic salts to field-grown potato tubers can suppress silver scurf during potato storage. Plant Dis. 83:814-818.

24. Orellana, R. G., Foy, C. D., and Fleming, A. L. 1975. Effect of soluble aluminum on growth and pathogenicity of Verticillium albo-atrum and Whetzelinia sclerotiorum from sunflower. Phytopathology 65:202-205.

25. Palmer, C. L., Horst, R. K., and Langhans, R. W. 1997. Use of bicarbonates to inhibit in vitro colony growth of Botrytis cinerea. Plant
Dis. 81:1432-1438

26. Platt, H. W. 1997. Resistance to thiabendazole in Fusarium species and Helminthosporium solani in potato tubers treated commercially in eastern Canada. Phytoprotection 78:1-10.

27. Punja, Z. K., and Gaye, M.-M. 1993. Influence of postharvest handling practices and dip treatments on development of black root rot on fresh market carrots. Plant Dis. 77:989-995.

28. Punja, Z. K., and Grogan, R. G. 1982. Effects of inorganic salts, carbonate-bicarbonate anions, ammonia, and the modifying influence of $\mathrm{pH}$ on sclerotial germination of Sclerotium rolfsii. Phytopathology 72:635-639.

29. Read, P. J., and Hide, G. A. 1984. Effects of silver scurf (Helminthosporium solani) on seed potatoes. Potato Res. 27:145-154.

30. Rodriguez, D. A., Secor, G. A., Gudmestad, N. C., and Francl, L. J. 1996. Sporulation of Helminthosporium solani and infection of potato tubers in seed and commercial storages. Plant Dis. 80:1063-1070.

31. Russell, N. J., and Gould, G. W. 1991. Food Preservatives. Blackie, London.

32. Secor, G. A., and Gudmestad, N. C. 1999 Managing fungal diseases of potato. Can. J. Plant Pathol. 21:213-221.

33. Secor, G., Gudmestad, N., and Rodriguez, D. 1996. NDSU making progress on management of silver scurf. Valley Potato Grow. July:26-27.

34. Smilanick, J. L., Margosan, D. A., Mlikota, F., Usall, J., and Michael, I. F. 1999. Control of citrus green mold by carbonate and bicarbonate salts and the influence of commercial postharvest practices on their efficacy. Plant Dis. 83:139-145.

35. Stevenson, W. R., Loria, R., Franc, G. D., and Weingartner, D. P. 2001. Compendium of Potato Diseases. 2nd ed. American Phytopathological Society Press, St. Paul, MN.

36. Yaganza, E. S., Arul, J., and Tweddell, R. J. 2001. Postharvest application of organic and inorganic salts for the control of potato tuber soft rot. (Abstr.) Phytopathology 91:S198. 